\title{
EFFECTS OF CULTURE SHOCK AND CROSS-CULTURAL ADAPTATION ON LEARNING SATISFACTION OF MAINLAND CHINA STUDENTS STUDYING IN TAIWAN
}

\author{
EFECTOS DEL CHOQUE CULTURAL Y DE LAADAPTACIÓN \\ INTERCULTURAL SOBRE LA SATISFACCIÓN CON EL APRENDIZAJE \\ DE LOS ESTUDIANTES DE LA CHINA CONTINENTAL QUE ESTUDIAN \\ EN TAIWAN
}

\author{
CHICH-Jen SHIEH charles@mail.cjcu.edu.tw \\ Chang Jung Christian University. Tainan City. Taiwan.
}

\begin{abstract}
With the national impact of low fertility, the enrollment of higher education in Taiwan is facing a dilemma. To cope with such a problem, the government has actively promoted Mainland China students to study in Taiwan. In addition to enhancing the international competitiveness of domestic universities, cross-strait education, and real academic exchange, it is expected to solve the enrollment shortage of colleges. However, the situations and pressures of Culture Shock, Cross-Cultural Adaptation, and Learning Satisfaction are critical for Mainland China students. Taking Mainland China students who study in Taiwan for more than four months (about a semester) as the research participants, a total of 250 questionnaires were distributed and 167 valid ones were retrieved, with a retrieval rate of $67 \%$. The research findings show significant correlations between Cross-Cultural Adaptation and Culture Shock, Culture Shock and Learning Satisfaction, and Cross-Cultural Adaptation and Learning Satisfaction.
\end{abstract}

\section{KEYWORDS}

China; Cross-Cultural Adaptation; Culture Shock; Learning Satisfaction; Personality Traits.

\begin{abstract}
RESUMEN
Debido al impacto de la baja fertilidad en el país, Taiwán afronta un dilema en relación con la inscripción en la enseñanza superior. Para enfrentarse al problema el gobierno ha promovido activamente que estudiantes de la China continental estudien en Taiwán. Además de incrementar la competitividad internacional de las universidades taiwanesas, la formación a ambos lados del estrecho y un verdadero intercambio académico, se espera que ello solucione la escasez de inscripciones en las facultades. Sin embargo, las situaciones y las presiones que generan el choque cultural, la adaptación multicultural y la satisfacción con el aprendizaje resultan críticas para los estudiantes de la China continental. Tomando como muestra de investigación a estudiantes de la China continental que estudian en Taiwán durante más de cuatro meses (aproximadamente un semestre), se distribuyó un total de 250 cuestionarios, de los cuales 167 fueron válidos, con una tasa de recuperación del $67 \%$. Los resultados de la investigación muestran correlaciones significativas entre la adaptación multicultural y el choque cultural, entre el choque cultural y la satisfacción con el aprendizaje y entre la adaptación multicultural y la satisfacción con el aprendizaje.
\end{abstract}

Palabras clave

Adaptación intercultural; China; Choque cultural; Rasgos de personalidad; Satisfacción con el aprendizaje. 


\section{INTRODUCTION}

The rapid development of technology and the popularity of the Internet have driven globalization and internationalization. To survive in knowledge economy societies (translated by $\mathrm{Fu}, 2009$ ), the cultivation of international talent has become important. International competence, which entails rapid integration with different cultures, emphasizes educational background as the minor, and stresses on international communication capabilities, i.e. chatting with people with distinct cultures, has changed from a "plus" into a "must". Numerous research on the adaptation of foreign students showed that international students faced not only academic pressure but also psychological, social, and cultural pressure from being in different environments. It was often discovered that international students were nervous in classes and dejected with the teachers' requirements and assignments. As the intercultural environments were different from the ones international students were accustomed to when growing up, such students were likely to become risk groups with serious diseases because they were lacking care and support from their parents, family, and friends and experienced inappropriate or abnormal diet and sleep, worse living quality, culture shock, or academic pressure.

Despite sharing the same language, the diet, culture, and environments are distinct between Mainland China and Taiwan. We wonder how Mainland China students, as international students, face Culture Shock, Cross-Cultural Adaptation, and Learning Satisfaction in Taiwan. Mainland China students, foreign students, and Overseas Chinese students therefore require counseling assistance and are expected to build up harmonic and friendly cross-strait relationships, promote the competitiveness of higher education, and enhance the positive exchange of cross-strait students. The situation of Culture Shock, Cross-Cultural Adaptation, and Learning Satisfaction and the pressure of Mainland China students are studied for appropriate counseling.

\section{LITERATURE REVIEW AND HYPOTHESIS}

\section{Culture Shock}

Culture Shock was first proposed in 1958, aiming to describe the chaotic emotions of a person being in a new environment in psychology (Trompenaars, 2006). Culture Shock refers to the effects of being in a familiar culture and getting into an unfamiliar one, experienced by people who work, live, or study abroad. Anyone could exhibit Culture Shock, as it aims to describe individual chaotic emotions when entering in a new environment. Culture Shock is closely related to cultural diversity, including shocks from new environments, new faces, and adaptation to exotic customs. Being apart from important people in one's life, such as family, friends, colleagues, or teachers, may make people feel uncomfortable when such familiar scenes, sounds, or atmospheres disappear (Lai, 2011). 
Chaney \& Martin (2007) defined Culture Shock as a wound which appears when a person moves from their original culture to a distinctly different one. Winkelman (1994) proposed that Culture Shock could result in psychological and physiological maladjustment encompassing psychology, physiology, emotion, interpersonal relationships, cognition, and society, as well as changes of socio-cultural relationships, cognition unbalance, and role pressure. Black \& Gregersen (1991) pointed out the importance of insecurity caused by a person leaving their familiar environment for an unfamiliar one. Some researchers indicated the effects of family conditions, past international experiences, age, and gender on Culture Shock. Personality Traits, Demographic Factors, and Organizational Support were found as the major factors in Culture Shock (Black \& Gregersen, 1999; Black, Mendenhall \& Oddou, 1991; Mendenhall \& Oddou, 1985) that difficulties in adapting to cultural differences could result in Culture Shock (Lan, 2012). For this reason, Personality Traits, Demographic Factors, and Organizational Support are regarded as the dimensions for Culture Shock in this study.

\section{Cross-Cultural Adaptation}

Cross-Cultural Adaptation is defined as the process of a person adapting to distinct cultural environments when encountering Culture Shock abroad. Caligiuri (2000) organized Cross-Cultural Adaptation as the new behaviors, regulations, and roles of people accepting foreign cultures and integrating the homeland culture abroad. When mentioning intercultural competence, Taylor (1994) considered that the transformation among cultures started in the stages of alienation and initial contact, followed by constantly testing new habits and hypotheses via trial and error, and ended at mutual dependence of retaining both cultures. Following Berry's research, Rieger \& Wong-Rieger, according to Tung (1993), proposed the process of Cross-Cultural Adaptation and defined it as the process of group members adapting to a different group culture from a cultural background. Berry proposed two dimensions for Cross-Cultural Adaptation, namely Culture Preservation and Partner Attractiveness, which were further divided by Rieger \& WongRieger into four high-functional and high-nonfunctional types to explain the interaction of Cross-Cultural Adaptation. Referring to Mendenhall and Oddou (1988), the dimensions of Personal Skills, People Skills, and Perception Skills are used as the dimensions for Cross-Cultural Adaptation in this study. Any methods helpful to psychological and emotional health are considered as Personal Skills, such as contemplation, prayer, regular exercise, time management, and authorization. People Skills indicate effectively exchanging with others, especially with foreigners. People who do not worry about grammatical errors tend to succeed in communicating with foreigners better than introverts. Perception Skills refers to the cognitive process assisting in understanding foreigners' behaviors, i.e. the personal ability to be aware of social glues and behaviors, concern affairs, and predict others' ideas. Mendenhall and Oddou also mentioned that preparation, keeping in touch, building up selection, and enjoying individual growth would help cultural adaptation. 


\section{Learning Satisfaction}

Huang (2012) regarded Learning Satisfaction as the perception and attitudes of learners participating in learning activities or the satisfaction with learning demands, resulting from learners' preferences and satisfaction with the entire learning activities. Lai (2010) identified Learning Satisfaction as the psychological perception of individual demands or wishes being fulfilled when participating in learning activities. High Learning Satisfaction refers to learners perceiving pleasure and satisfaction after the demands or wishes have been achieved. Chi (2011) regarded Learning Satisfaction as the learners' learning expectations before learning activities are achieved with saturated pleasure and active attitudes. Fang (2011) considered Learning Satisfaction as the learners' perception and responses to the learning contents or activities after participating in the entire learning process that the higher the learning pleasure and satisfaction were perceived, the higher was the appeared satisfaction.

Huang (2012) concluded six dimensions for Learning Satisfaction, including Administrative Support, Teacher Instruction, Curriculum, Interpersonal Relationships, Learning Outcomes, and Learning Environment. Wei (2011) organized four dimensions for Learning Satisfaction, containing Teacher Instruction, Curriculum, Learning Environment, and Administrative Services. Huang (2012) pointed out the dimensions of Self-Development, Interpersonal Relationships, Contents of Materials, and Learning Performance for Learning Satisfaction. Tsai (2012) proposed five dimensions of Curriculum and Materials, Teacher Instruction, Learning Environment, School Administration, and Learning Outcomes for Learning Satisfaction. Fang (2011) indicated Teacher Instruction, Curriculum, Learning Environment, and Administrative Services as the dimensions for Learning Satisfaction.

Based on the above research for adult members, the Learning Satisfaction Scale, with the dimensions of Curriculum, Teacher Instruction, Administrative Support, Learning Environment, Learning Outcomes, and Interpersonal Relationships, is applied to explaining the Learning Satisfaction of foreign students. Mainland China students studying in Taiwan are selected as the research participants. Referring to the above research and literature reviews on Learning Satisfaction, the Learning Satisfaction Scale of Mainland China Students Studying in Taiwan is developed, containing the dimensions of Teacher Instruction, Curriculum, Learning Outcomes, Interpersonal Relationship, and Administrative Services.

\section{Correlations among Culture Shock, Cross-Cultural Adaptation, And Learning Satisfaction}

Lin \& Yi (1997) mentioned that international students would encounter racial discrimination, language barriers, adaptation difficulties, diet maladjustment, financial stress, culture shock, and cross-cultural adaptation. Under unfamiliar environments, emotio- 
nal responses of anxiety, confusion, and depression would result in mental disorders, loneliness, insomnia, and physical discomfort which influence learning satisfaction. Shih (2011) discovered in the research on social support and life adaptation processes of international students that (1) international students would present better Learning Satisfaction by understanding the learning motivation and actively seeking Cross-Cultural Adaptation. (2) international students aimed to seek for Cross-Cultural Adaptation support from family or foreign students, but revealed positive attitudes towards Taiwanese students, and (3) international students exhibited different adjustments according to distinct external environments and intrinsic factors, including learning intention, culture shock, cross-cultural adaptation, academic pressure, and homesickness. Lin \& Yi (1997) indicated the difficulties of international students in Cross-Cultural Adaptation in the USA, and the academic difficulties showed positive correlations with Cross-Cultural Adaptation. Students might not easily understand the lessons because of professors' accents and Culture Shock which caused a lack of interest in class discussions and reduced Learning Satisfaction. Liu (2010) discussed with foreign students in Taiwan and found that (1) Cross-Cultural Adaptation was the major problem for foreign students. (2) Culture Shock was a great challenge for most foreign students, and most foreign students would apply active and positive attitudes towards life adaptation and frustration to enhancing Learning Satisfaction.

\section{Research Hypothesis}

According to the above literature reviews, the following research hypotheses are inferred.

H1: Cross-Cultural Adaptation presents significant correlations with Culture Shock.

$\mathrm{H}$ 2: Culture Shock shows remarkable correlations with Learning Satisfaction.

H3:Cross-Cultural Adaptation presents notable correlations with Learning Satisfaction.

\section{DESIGN OF RESEARCH METHODOLOGY}

\section{Operational Definition and Measurement of Variables}

\section{Culture Shock}

The dimensions of Personality Traits, Demographic Factors, and Organizational Support are included for Culture Shock. The scale refers to Black \& Gregersen (1991), and the questions are scored with Likert's 7-point scale, where 1 stands for Extremely Disagree and 7 for Extremely Agree. The overall reliability coefficient of the Personality Traits appears to be 0.84 , Demographic Factors is 0.82 , and Organizational Support is 0.80 . 


\section{Cross-Cultural Adaptation}

Cross-Cultural Adaptation covers the dimensions of Personal Skills, People Skills, and Perception Skills. The scale is referred to by Mendenhall \& Oddou (1988), and the questions are scored with Likert's 7-point scale, where 1 stands for Extremely Disagree and 7 for Extremely Agree. The overall reliability coefficient of Personal Skills is registered as 0.81 , People Skills as 0.80 , and Perception Skills as 0.86 .

\section{Learning Satisfaction}

The Learning Satisfaction Scale refers to Tsai's research (2010), and the questions are scored with Likert's 7-point scale, where 1 stands for Extremely Disagree and 7 for Extremely Agree. The overall reliability coefficient of Teacher Instruction is 0.81 , Curriculum is 0.80 , Learning Outcomes is 0.80 , Interpersonal Relationships is 0.80 , and Administrative Services is 0.86 .

\section{Research participants}

Aiming at Mainland China students studying in Taiwan, Culture Shock, Cross-Cultural Adaptation, and Learning Satisfaction are studied. Short detention time in Taiwan might affect the research on Culture Shock and Cross-Cultural Adaptation that Mainland China students who stay in Taiwan for more than four months (about a semester) are selected as the research participants. The top five colleges, including Shih Hsin University, Feng Chia University, Ming Chuan University, Chung Yuan Christian University, and I-Shou University, which enrolled the most Mainland China students in 2012, are selected for distributing 250 questionnaires. A total of 167 valid questionnaires are retrieved, with a retrieval rate of $67 \%$.

\section{Test of Reliability and Validity Analyses}

The reliability of the dimensions achievements above 0.7 shows a high reliability. The construct validity is analyzed with Confirmatory Factor Analysis, Table 1, where both convergent validity and construct validity are favorable.

Table 1.

Confirmatory Factor Analysis

\begin{tabular}{l|l|c}
\hline \multicolumn{1}{c|}{ Dimension } & \multicolumn{1}{c|}{ Overall fit } & Result \\
\hline Culture Shock & $\mathrm{X} 2=0(\mathrm{P}<0.001) ; \mathrm{DF}=0 ; \mathrm{GFI}=1.00 ; \mathrm{CFI}=1.00$ & Excellent fit of the overall model \\
Cross-Cultural Adaptation & $\mathrm{X} 2=0(\mathrm{P}<0.001) ; \mathrm{DF}=0 ; \mathrm{GFI}=1.00 ; \mathrm{CFI}=1.00$ & Excellent fit of the overall model \\
Learning Satisfaction & $\mathrm{X} 2=0(\mathrm{P}<0.001) ; \mathrm{DF}=0 ; \mathrm{GFI}=1.00 ; \mathrm{CFI}=1.00$ & Excellent fit of the overall model \\
\hline
\end{tabular}

Source: Self-organized in this study. 


\section{AnALYSIS RESULtS}

\section{Correlation Analysis}

From Table 2, Culture Shock, Cross-Cultural Adaptation, and Learning Satisfaction present significant correlations, showing the multicollinearity among the dimensions. Niehoff and Moorman (1993) suggested utilizing the Nested Model to solve such a problem. The significant correlations among the dimensions reveal the correspondence with the hypotheses.

Table 2.

Correlation Analysis

\begin{tabular}{l|c|c|c|c}
\hline \multicolumn{1}{c|}{ Dimension } & $\alpha$ & Culture Shock & Cross-Cultural Adaptation & Learning Satisfaction \\
\hline Culture Shock & 0.81 & & & \\
Cross-Cultural Adaptation & 0.85 & $0.36^{* \star}$ & & \\
Learning Satisfaction & 0.82 & $0.31^{* \star}$ & $0.29^{\star \star}$ & \\
\hline
\end{tabular}

Source: Self-organized in this study.

\section{Discussion Of Theoretical Model}

The research results (Figure 1) are presented below, in which the path coefficients achieving significance are marked with solid lines, while the ones not achieving significance are marked with dotted lines. Apparently, all path coefficients achieve significance, presenting the path coefficients reaching convergent validity which corresponds to the basic requirement of the analysis model. Moreover, the fit of the model is confirmed, according to the indices of fitness, GFI $=0.932$, AGFI $=0.916$, RMSEA $=0.03, C F I=0.984$, and the research model conforms to the theory and is valid.

\section{Discussion of Research Hypothesis}

With the Nested Model, the hypotheses are tested with a Chi Square Test, as each Nested Model depicts a degree-of-freedom difference. When the chi square value of the Nested Model is deducted from the chi square value of the theoretical model and achieves significance, the path coefficient set 0 is remarkable. The research results show that the model achieves significance. The Nested Model Analysis is shown in Table 3, and the test of the hypotheses is presented in Table 4. 


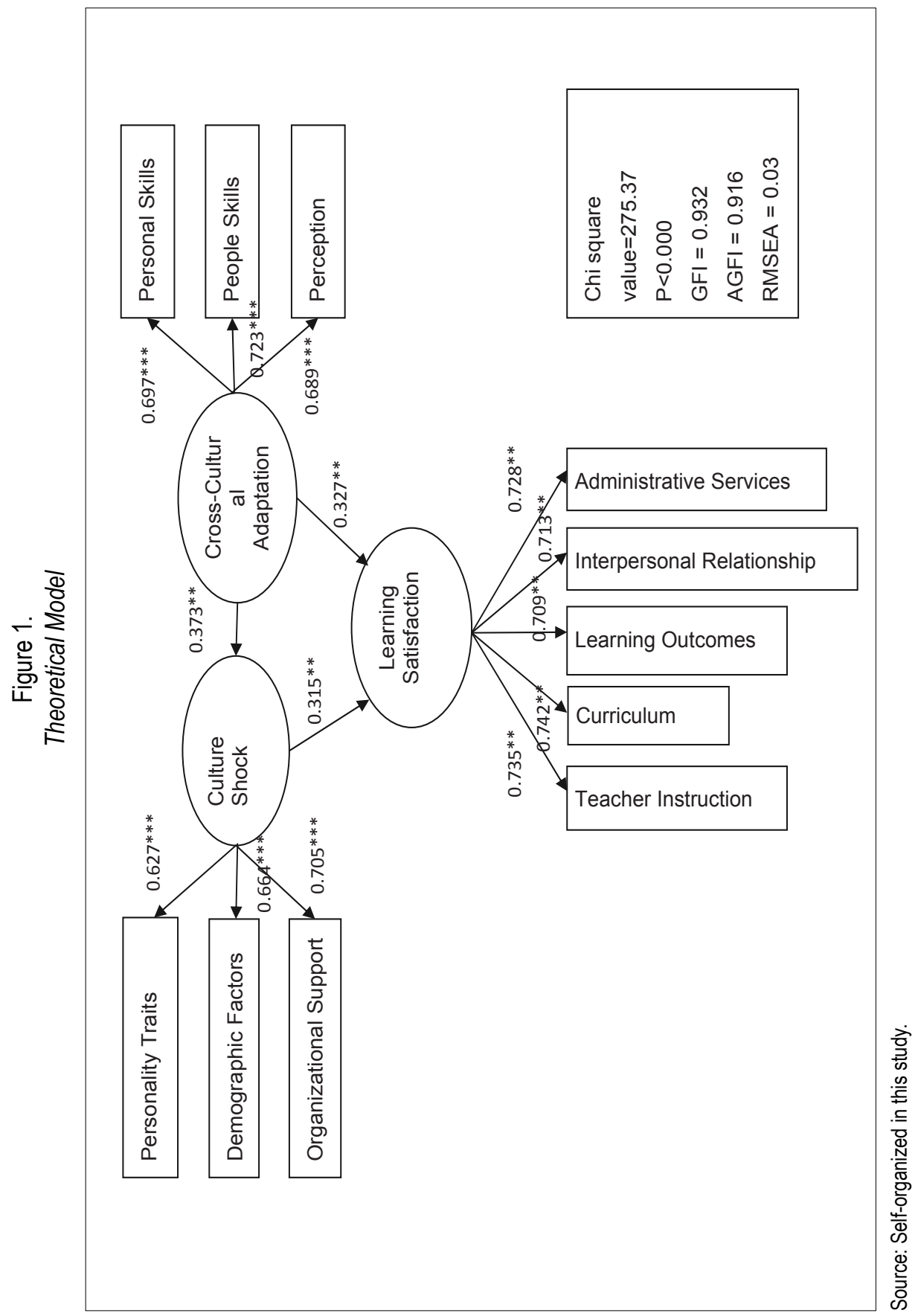

RIS, VOL.72. EXTRA 2, 57-67, NOVIEMBRE 2014. ISSN: 0034-9712. DOI: 10.3989/ris.2013.08.10 
Table 3.

Nested Model Analysis

\begin{tabular}{lccccc}
\hline Model & $\mathrm{X} 2$ & $\Delta \chi^{2}$ & GFI & CFI & RMSEA \\
\hline Theoretical model & 275.37 & & 0.932 & 0.984 & 0.03 \\
Model 1: Hypothesis test & 281.49 & $6.12^{*}$ & 0.932 & 0.984 & 0.03 \\
Model 2: Hypothesis test & 287.37 & $5.88^{\star}$ & 0.932 & 0.984 & 0.03 \\
Model 3: Hypothesis test & 294.68 & $7.31^{*}$ & 0.932 & 0.984 & 0.03 \\
\hline
\end{tabular}

Source: Self-organized in this study.

Table 4.

Hypothesis test

\begin{tabular}{lcccc}
\hline Hypothesis & Correlation & Empirical result & $\mathrm{P}$ & Result \\
\hline $\mathrm{H} 1$ & + & 0.373 & 0.00 & Supported \\
$\mathrm{H} 2$ & + & 0.315 & 0.00 & Supported \\
$\mathrm{H} 3$ & + & 0.327 & 0.00 & Supported \\
\hline
\end{tabular}

Source: Self-organized in this study.

\section{Conclusions AND SUggestions}

The research results present the significant correlations between Culture Shock and Cross-Cultural Adaptation that the results and the findings are concluded for the following practical suggestions.

\section{Establishing Special Learning Classes By Integrating Mainland China Students}

The results show Interpersonal Relationships as the key factor in Cross-Cultural Adaptation. Consequently, the educational authority could integrate Mainland China students in various colleges and establish special learning classes, under allowable budgets, to attract Mainland China students to study in Taiwan. Under peer encouragement, they could enhance their Personal Skills, reduce Culture Shock, and promote Cross-Cultural Adaptation and Learning Satisfaction.

\section{Reinforcing Professional Teacher Training}

Teacher Instruction is discovered as a key factor in Learning Satisfaction in this study. In this case, the professional role of teachers is generally respected and the importance of teachers in colleges is apparent. Implanting Taiwan culture and customs into the minds of Mainland China students through Teacher Instruction relies on professional teacher 
training. Current courses are taught by Taiwanese teachers, who present enthusiastic instruction but are lacking in experience in communicating with Mainland China students who may be hindered in learning the information due to culture shock. The government should regularly hold professional teacher training sessions to establish communication with Mainland China students and to cultivate individual Perception Skills of Mainland China students for Cross-Cultural Adaptation.

\section{Diverse Curriculum}

The curriculum is regarded as a key factor in Learning Satisfaction. In addition to the taught subjects, teachers should integrate lessons covering traditional festivals and rituals as well as laws and medical resources related to individuals into the curriculum. The schools may also hold social events for Mainland China students and native students to encourage them to integrate into the native culture to reduce their culture shock and enhance their learning satisfaction.

\section{References}

Black, J. S., and Gregersen, H. B. 1991. "The other half of the picture: Antecedents of spouse crossculture adjustment." Journal of International Business Studies 22(4): 671-694.

Black, J. S., and Gregersen, H. B. 1999. "The right way to manage expatriates." Harvard Business Review 77(2): 52-63.

Black, J.S., Mendenhall, M., and Oddou, G 1991. "Toward a comprehensive model of international adjustment: An integration of multiple theoretical perceptive." Academy of Management Review 16(2): 291-317.

Caligiuri, P. M. 2000. "The big five personality characteristics as predictors of expatriate's desire to terminate the assignment and supervisor-rated performance." Personnel Psychology 53(1): 67-88.

Chaney, L. H. and Martin, J. S. 2007. Intercultural Business Communication, 4th ed. New Jersey: Prentice-Hall, Inc.

Chi, Wen-wei 2011. "The impact of degrees of learning involvement, learning satisfaction on the intention for continuing study - the example of Yulin community college." Bulletin of Adult \& Continuing Education 29: 197-219.

Fang, Suh-mei 2011. "Self-directed Learning Intention and Learning Satisfaction of Members in Kaohsiung County Community University." Educational Research \& Information 11(1): 115-143.

Fu, Chen-kun 2009. Written by Drucker, P. Post-Capitalist Society. Taipei: China Times Publishing.

Huang, Ming-yu 2012. "Research of relationship among self-directed learning readiness, classroom climate and learning satisfaction of adult learners." Yearbook of Education, 95: 259-288.

Huang, Yu-shiang 2012. "The Study on Learning Motivation and Learning Satisfaction degree in Community College Learners." Adult Education 68: 25-34. 
Lai, Mei-chun 2011. "A Study of Culture Shock, Culture Adjustment and Learning Strategy-The Experience of International Exchange Students Studying in the United States." Educational Research \& Information 11(1): 115-143.

Lai, Shu-feng 2010. "Learning Motivation and Learning Satisfaction of Members in Taoyuan County Community University." National Policy Quarterly 2(4): 1-22.

Lan, Ya-hsin 2012. "A Study On the Relationships among the Cross-Cultural Training,Expatriate Skill and Expatriate Adjustment." Journal of Secondary Education 10: 133-182.

Lin, J., and Yi, J. 1997. "Asian international students' adjustment: Issues and program suggestion." College Student Journal 31(4): 473-479.

Liu, Pin-yo 2010. "Foreign Students' Life Adjustment and Career Development in Taiwan- Foreign students in National Tsing-Hua University and National Chiao Tung University. New Waves." Educational Research and Development 7(1): 7-12.

Mendenhall, M., and Oddou, G. 1985. "The dimensions of expatriate acculturation." Academy of Management Review 10(1): 39-47.

Mendenhall, M. E. and Oddou, G. 1988. "The overseas assignment: A practical look." Business Horizons 31(5): 78-84.

Niehoff, B. P. and R. H. Moorman 1993, "Justice as a Mediator of the Relationship between Methods of Monitoring and Organizational Citizenship Behavior." Academy of Management Journal 36(3): 527-56.

Shih, Hisu-ling 2011. "Investigation of international students' social support and life adjustment in Taiwan-A case study of Ming Chuan University Taoyuan Campus' international students." Journal of Kaohsiung Hospitality College 3: 53-68.

Taylor, E. W. 1994. "Intercultural Competency: A Transformative learning process." Adult Education Quarterly 44 (3): 154-174.

Trompenaars, F. (2006). "The culture shock of mergers and acquisitions." Alexander Hughes European Newsletter 29: 3-4.

Tsai, Su-lin 2012. "Learning Satisfaction with Literate Education of Foreign Spouses from Multi-Cultural Aspects." Journal of Chung Hua Language 2: 243-269.

Tung, R. L. 1993. "Managing cross-national and intra-national diversity." Human Resource Management (32)4: 461-477

Wei, Yin-ho 2011. "The Study on Learning Satisfaction and its Related Factors of Students in Community College in Tainan City." NTU Management Review 10(2): 31-39.

Winkelman, M. 1994. "Cultural shock and Adaptation." Journal of Counseling and Development 73(2): 121-130.

Dr. Chich-Jen Shieh is a Professor at the Department of International Business, Chang Jung Christian University, TAIWAN, No.1, Changda Rd., Gueiren District, Tainan City 71101, TAIWAN. His researches interested are in International marketing Management, International Human Recourse Management, Operational and Production Management.

RECEIVED: 10 August 2013.

ACCEPTED: 27 February 2014.

PUBLISHED ONLINE: 09 May 2014. 